成績と考える。

結論 血清中の抗ダニ, 抗ヨモギ $\mathrm{IgE}-\mathrm{Ab}$ 価は,
40〜100回の凍結融解の反復にも安定であった。血清の

保存上有意義な知見と考える。

\title{
86. 内視鏡的鼻内副鼻腔手術のための局所麻酔
}

\author{
馬場千恵子 ·岩崎光雄・江崎史朗・大西俊郎（聖路加国際） 足川力雄（東京厚生年金）
}

近年，鼻内副鼾腔手術に扔いて内視鏡の導入がさか んになるにつれ，手術を用滑かつ確実に遂行するため には, 術野の出血㧍よび疼痛のコントロールがますま す重要になってきている，今回我々は，この目的にか なう鼻内局所麻酔法を検討し，コカインの有用性を再 認識したのでその方法と効果を報告した。

方法 1 . 綿棒にてまず $4 \%$ \%ドカイン(含エピネフ リン)を総鼻道 $\rightarrow$ 鼻中隔 $\rightarrow$ 嗅裂 $\rightarrow$ 中甲介 $\rightarrow$ 舅堤 $\rightarrow$ 中鼻 道一しん門部の順に塗布し，さらに5\%コカインを同 部位に十分塗布する。2. 嗅裂, 中鼻道に $4 \%$ リドカイ ン，5\%コカインをそ机ぞれ含ませたがーゼを㧴入し 約 10 分間留置する.3. 以上塗布麻酔比て鼻粘膜を十分 収斂させ中鼻道を開かせたのち，1\%リドカイン（含 エピネフリン)を中甲介，鼻堤，しん門部に浸潤させ る.

使用麻酔真 a. 塗布麻醉： $4 \%$ リドカイン(含エピ ネフリン) 約 $2 \mathrm{ml}, 5 \%$ ユカイン約 $1 \mathrm{ml}$. b. 浸潤麻醉： $1 \%$ リトカイン (含エピネフリン) 約 $5 \mathrm{ml}$.

対象 内視鏡的鼻内副鼻腔手術施行30症例，49側 年齢 20 歳 $\sim 68$ 歳.
結果 当麻酔法の効果を判定するために疼痛に関す るアンケートを施行したところ，実際の手術時の痛み が手術前に予想していた痛みより軽かったとする回答 が78\%を占めた。また出血においては定量的検討を行 わなかったが, 術中出血量は少なく，内視鏡下の視野 は十分保たれた。一方，全身的変化のため手術を一時 中断した症例が $12 \% に$ 認められた。血圧低下 5 側，血 圧低下㧍よで徐脈 1 側でいずれも，手術体位の変換等 により軽快し手術の続行が可能で，急性中毒症状とは 考えにくかった。以上より, 疼痛, 出血の制御が重要 なポイントである内視鏡下鼻内副鼻腔手術において本 法は安全かつ有用な局所麻酔法上考えられた。質 問 吉見充徳 (同愛記念). 術前の疼痛予測とはどのよ うに行うのか。応答 疼痛程度を 0 から10までの スケールで表し, 術前予想していた程度と実際の手術 時の程度をアンケートにて調查した。追加足川 力雄 (東京厚生年金)。コカイン，管骨神経・動脈ブロ ックは出血や疼痛抑制に極めて効果的である。コカイ ン液は欧米でも利用されており，Draf 教授は最良の止 血剤でもあるといっている。

\section{7. 内視鏡下副鼻腔鼻内手術の術後経過}

小林憲明・横山和則・松井 都 - 山下公一（金沢医大）

目的内視鏡を導入した慢性副鼻腔炎の鼻内手術が 多く行われるようになっているが，その術後経過のコ ントロールは重要な要因となるので,これを観察し, 問題点を検討した。

対象 過去 5 年間に当科で同手術を行った 49 症例の 術後経過を調查した。種々の事情で術後の長期経過観 察が不可能だった症例が10例あった。術後継続的に通 院し，内視鏡所見，X線写真，C丁などによる経過記録 が明確な症例は39例で，これにつき検討した。

結果 (1) 術後経過記録から, 比較的平滑に治痛した ことが確認された症例は22/39例（56.4\%）であった。 (2) 術後経過に問題があったものが17/39例 (43.6\%), うち 4 例には再手術が行われた。問題点は，保存副鼻 腔粘膜の浮腫性炎症性病変の遷延, 開放した副鼻腔の 交通路に生じた癒着狭窄などであった。図は結果を年 齢別に示したものでる.10歳台と50歳台の症例で術 後治瘾が僄延する傾向が大きかった。

考察 10 歳台で注副嶨腔が狭く未熟で，上皮化が期

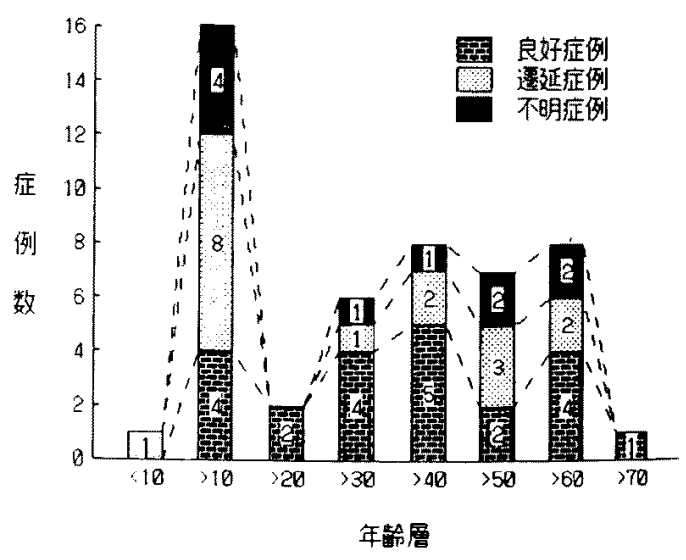

待通りに行われにくい印象があり，50歳台で術前の 炎症の程度が関与しているように思われた。

まとめ 内視鏡下鼻内手術療法の原理は, 副鼻脂粘 